\title{
Geoecological research of water bodies of the Central Federal District of different recreational availability
}

\author{
Ekaterina Chekmareva* \\ Water Problems Institute, Ivankovskaya Research Station, Russian Academy of Sciences \\ Belavinskaya 61a, 171251, Konakovo, Russia
}

\begin{abstract}
The results of geoecological research on water bodies of the Central Federal District of Russia are presented. Recreational availability of water bodies determines the level of access to water bodies and the coastal zone and their use for recreational activities by several geoecological characteristics and indicators. The studies included water sampling for chemical, microbiological analysis, and water quality assessment of water bodies and watercourses in the Central Federal District. Databases of morphometric and hydrological characteristics of water bodies have been compiled, access to the coastal zone and water area of reservoirs has been assessed. The recreational potential of water bodies is calculated based on the load on the generally accessible coastal zone, it is specified by natural and cartographic data. It was found that most water bodies have a ban on recreational water use. This is due to poor water quality in chemical and microbiological terms. Most water bodies are insufficiently surveyed and do not have equipped areas for recreational use. Recreation areas are located locally, the water bodies banks are heavily loaded in the summer. This leads to the degradation of the vegetation cover, contamination and re-compaction of the soil, the emergence of unauthorized dumps, increased pressure on the water body areas, the risk of spreading infectious and skin diseases. Access to the coastal zone of water bodies and watercourses in the Moscow Region and adjacent regions is also a problem. This is due to the high level of construction of building near large reservoirs, rivers, and lakes.
\end{abstract}

\section{Introduction}

Tourism and recreational resources are an important area of economic development in many countries and Russia is no exception. The strategy of socio-economic development of the subjects of the Russian Federation until 2030 aims for the preservation and restoration of water bodies to a state that provides favorable living conditions for the population, rational use of natural resources, tourism development [1].

The use of the water area and coastline of water bodies for various types of recreational activities (recreation, sports, tourism) is called recreational water use [2,3].

\footnotetext{
*Corresponding author: e_al_cheva@iwp.ru
} 
The majority of water bodies in the Central Federal District (CFD) of Russia have a ban on recreational water use due to poor water quality on microbiological, parasitological and chemical (quality class "polluted" and "dirty") indicators. "The pollution of the aquatic environment means the introduction by man directly or indirectly, of substances or energy which result in such deleterious effects as harm to living resources, a hazard to human health, hindrance to aquatic activities" [4]. Swimming is prohibited in $71 \%$ of the studied zones of active water use of the CFD of Russia, the signs "no swimming" are placed. Recreation areas are located locally, and the banks of water bodies are heavily loaded in summer due to the high population density of the CFD of Russia $\left(60.56\right.$ people per $1 \mathrm{~km}^{2}$, as of January 1, 2019) [5]. Thus, on the territory of Moscow (population of the city -12.6 million people), there are 11 recreation areas with bathing and 48 recreation areas without bathing [6]. This leads to degradation and destruction of the vegetation cover, contamination, re-compaction of the soil, and changes in soil filtration characteristics, the appearance of unauthorized dumps, an increase in chemical and microbiological load (isolation of compounds of nitrogen, phosphorus, chlorine, bacterial flushing from the human body) on the reservoir, the risk of spreading infectious and skin diseases.

The CFD of Russia has a low level of road network coverage compared to other countries. This is due to the large area of the CFD of Russia, intense urbanization and uneven distribution of the population [7].

Access to the coastal zone of water bodies and streams in the Moscow Region and adjacent areas is limited in some areas. This is due to the high level of construction of private houses and cottage settlements near reservoirs, rivers, and lakes.

In 2018, the concept of recreational-available water bodies was introduced [7]. Any water body and watercourse can be considered available for recreational use, which can be accessed without significant obstacles, there is free access to the coastal zone and water area; hydrological regime, hydrochemical, microbiological, thermal condition of the water body do not threat the human health during its use.

There are different access levels to the water body and its coastal zone.

1. Recreational-available: meet all parameters, with no restrictions on safe operation;

2. Recreational-available with restrictions: do not correspond to all indicators insignificantly, indicators can be improved, have limitations to safe operation;

3. Recreational-available with strong restrictions: do not correspond to all indicators to a large extent, indicators are difficult to improve, have limitations to safe operation;

4. Recreational-unavailable inaccessible: do not conform to indicators with restrictions on safe operation.

These levels depend on transport accessibility, level of infrastructure development, proximity to pollution sources and other characteristics: morphometric, hydrological, ecological, water quality, the overgrowth level of higher aquatic vegetation, access to the shore (whether there are buildings or not), presence of forests and swamps on the territory.

There are difficulties in identifying the load on recreational areas. In this study the method of calculating the number of holidaymakers at peak loads, modern methods of observation - installation of a video camera and shooting from the quadcopter, is used. It is difficult to predict the number of tourists, it is due to climatic changes in Russia in recent years.

The research objects are located in Moscow, Vladimir, Kaluga, Lipetsk, Moscow, Nizhny Novgorod, Ryazan, Smolensk, Tambov, Tver, and Tula Regions (Table 1). 
Table 1. Morphometric and hydrological characteristics (min-max) of the water bodies under study in the CFD of Russia.

\begin{tabular}{|l|c|c|}
\hline & Reservoir & Lake \\
\hline Area/volume, km ${ }^{\mathbf{2}}$ & $1.5-327 / 0.06-1245$ & $0.05-8.5 /-$ \\
\hline Length/width, km & $2.5-146 / 0.8-3.5$ & $0.4-5.0 / 0.1-3.5$ \\
\hline Depth (average/max), m & $2.5-6.7 / 7-23$ & $2.5-4.5 / 3.8-28$ \\
\hline Flow rate, m/s & $0.1-0.5$ & - \\
\hline
\end{tabular}

The areas with fast current are not suitable for safe bathing. The flow rate shall not exceed $0.5 \mathrm{~m} / \mathrm{s}$ [8].

The bottom of reservoirs and watercourses can be covered with sand, pebbles, gravel, stones, submerged earth, remnant vegetation and tree, shells, sediment, concrete, artificial film, and may also contain glass and household rubbish. The bottom of the reservoir, the bathing area, and water sports areas must be inspected and cleaned regularly.

\section{Methods}

In June-September 2010-2011, 2016, 2018 and 2019 water samples were taken from water bodies (reservoirs, lakes and artificial reservoirs) and watercourses for chemical analysis (123 water samples), in 2018 for microbiological analysis (36 water samples). Water sampling was carried out from a depth of 0.4-0.5 meters in the water use areas subject to the highest recreational load under GOST 3161-2012 "Water. General requirements for sampling" and GOST 31942-2012 "Water. Sampling for microbiological analysis" [9, 10]. Sample analysis was carried out by standard methods in Ivankovskaya research station (Konakovo, Tver Region), the certified chemical laboratory (accreditation certificate RA.RU.21AH96 of 28.10.2016) of the branch of Water Problems Institute. Chemical analysis of water was carried out on physical and chemical indicators (temperature, $\mathrm{pH}$, electrical conductivity, turbidity, suspended matters), macro-component composition $\left(\mathrm{HCO}_{3}, \mathrm{Ca}, \mathrm{Mg}, \mathrm{SO}_{4}, \mathrm{Cl}, \mathrm{Na}\right.$, and $\mathrm{K}$ ), biogenic elements (Fe, $\mathrm{Si}, \mathrm{N}$ and $\mathrm{P}$ compounds), indicators of organic compounds $\left(\mathrm{BOD}_{5}, \mathrm{COD}\right.$, permanganate index, chromaticity), the content of oxygen, oil products, synthetic surfactants. Research methods: titrimetric, iodometric, gravimetric, potentiometric ( $\mathrm{pH}$-meter-ionometer "Ecotest 2000I"), photometric (spectrophotometer B-1100), infrared spectrophotometry (concentrator KN-2m IshVZh.010). Microbiological research (coliform bacteria, thermotolerant coliforms, coliphages, intestinal pathogens) was performed in the certified laboratory of the FBHI branch "Center of Hygiene and Epidemiology in the Moscow region" (Klin, Moscow region). Water quality was assessed by the maximum permissible concentration (MPC) of chemicals in the water of water objects of cultural and household water use [11].

To assess the recreational potential, we used the coastal zone area, considering that the width of the coastal strip of public water bodies is $20 \mathrm{~m}$ [12]. Recreational potential, in this case, is the number of people who can rest near a water body or watercourse, provided that the entire coastal zone is used:

$$
R_{p}=\frac{L_{s} \cdot 20}{5}
$$

$R p$ - recreational potential of the water body (thousand people), $L s$ - length of the shoreline (m), 20 - width of the shoreline of public water bodies (m) [12], 5 - minimum area of the coastal zone of freshwater bodies per 1 person $\left(\mathrm{m}^{2}\right)[8]$. 
This value characterizes well the potential of small water bodies (lakes, quarries filled with water, ponds). Not the entire coastline is accessible and suitable for recreation. The coastal zone is unsuitable for use due to lack of access roads, forest or marshy approaches to water and dense construction. With the help of geoecological mapping of the coastal zone, it is possible to assess the possibility of using the water body for recreational water use. Geoecological mapping of the coastal zone allows allocating the following areas: lands of settlements, lands near roads and bridges, wetlands, forested areas, areas suitable for recreational water use (with free access to the water body). Separately, the area of recreational zones currently in operation is allocated.

\section{Results and Discussion}

According to the results of studies in the CFD of Russia, water in water bodies and watercourses is mainly small (up to $0.2 \mathrm{~g} / \mathrm{dm}^{3}$ ) and medium $\left(0.2-0.5 \mathrm{~g} / \mathrm{dm}^{3}\right.$ ), less frequently of high mineralization $\left(0.5-1.0 \mathrm{~g} / \mathrm{dm}^{3}\right)$ [13], of a hydrogen carbonate composition, in terms of water hardness from very soft (up to $1.5 \mathrm{mg}$-eq. $\left./ \mathrm{dm}^{3}\right)$ to hard $\left(6-9 \mathrm{mg}\right.$-eq. $\left./ \mathrm{dm}^{3}\right)$, with neutral and slightly alkaline $\mathrm{pH}$. Alkaline water $\mathrm{pH}>8.5 \mathrm{pH}$ can be irritating and is a favorable environment for skin diseases. Chemical analysis of water samples for several hydrochemical characteristics is presented in Table 2.

Table 2. Value ranges (min-max) of some hydrochemical characteristics of investigated water bodies of the CFD of Russia in 2018-2019, $\mathrm{mg} / \mathrm{dm}^{3}$ (color index- degree).

\begin{tabular}{|l|c|c|c|c|}
\hline & Reservoir & Lake & $\begin{array}{c}\text { Quarries/ } \\
\text { ponds }\end{array}$ & River \\
\hline Mineralization & $212-370$ & $107-496$ & $143-600$ & $160-840$ \\
\hline Silicon & $0.39-3.2$ & $0.37-6.1$ & $0.17-17.3$ & $0.29-4.9$ \\
\hline Total iron & $0.03-0.13$ & $0.03-0.17$ & $0.04-0.11$ & $0.03-4.25$ \\
\hline Nitrates & $0.19-2.3$ & $0.14-2.7$ & $0.13-2.3$ & $0.19-37.3$ \\
\hline Phosphates & $0.010-0.707$ & $0.014-0.053$ & $0.011-1.14$ & $0.010-3.36$ \\
\hline Oil products & $0.011-0.39$ & $0.003-0.01$ & $0.012-0.25$ & $0.002-0.29$ \\
\hline Color index & $13-57$ & $10-80$ & $8-35$ & $13-560$ \\
\hline Turbidity & $0.41-17.8$ & $0.35-43.5$ & $0.52-34.4$ & $0.6-20.6$ \\
\hline Gross lead & $0.004-0.009$ & $0.006-0.009$ & $0.009-0.018$ & $0.0018-0.018$ \\
\hline
\end{tabular}

Discharge of wastewater, flushing from the territory of settlements, surface flow from agricultural fields lead to increased concentrations of sulfates and chlorides, sodium and potassium, phosphorus and nitrogen compounds, oil products, $\mathrm{BOD}_{5}$, synthetic surfactants. Regional features of water quality are high chromaticity and significant concentrations of iron common in the conditions of marsh water supply. There are high concentrations of silicon. Water with high turbidity, high color index, covered with a biological film of phytoplankton and film of oil products causes water users to doubt its quality, spoils the aesthetic appearance of the water body.

Microbiological analysis has revealed noncompliance with RF standards [14] for coliform bacteria and thermo tolerant coliform bacteria. Of the 36 water samples, $17 \%$ did not meet sanitary and epidemiological requirements, where the content of coliform bacteria was 500 and more CFUs in $100 \mathrm{ml}$ of the test water [15]. 


\section{Conclusions}

Lack of good water quality is due to improper placement of recreation areas (without regard to sources of pollution). Water bodies are insufficiently explored, they do not have equipped areas for recreation, or these areas are poorly equipped. Most recreational areas near water bodies are used for recreation without bathing.

In places of intensive recreational load, the concentration of total iron and sulfates (5 times), nitrates and nitrites (30 and 53 times) in soils are increasing compared with the natural background [16], as well as lead and petroleum products. This is due to the unauthorized placement of cars, the lack of toilets near recreation areas, the creation of catering facilities, picnic and beach areas near the water body.

The results of the recreational potential assessment are shown in Table 3.

Table 3. Estimation of the recreational potential (min-max) of the studied lakes and artificial water bodies in the CFD.

\begin{tabular}{|l|c|c|c|}
\hline \multicolumn{1}{|c|}{ Characteristic } & Lake & Pond & Quarries \\
\hline $\begin{array}{l}\text { S water areas, } \\
\text { thou. } \text { m }^{2}\end{array}$ & $7.0-12340.3$ & $27.8-98.3$ & $70.8-978.5$ \\
\hline $\begin{array}{l}\text { S coastal public access zone } \\
\text { thou. } \text { m }^{2}\end{array}$ & $6.3-500.3$ & $17.6-39.2$ & $24.0-96.4$ \\
\hline S active beach areas, \% & $0.1-45$ & $1.9-11.2$ & $15.8-41.4$ \\
\hline $\begin{array}{l}\text { Recreational potential, } \\
\text { thou. people }\end{array}$ & $0.16-11.2$ & $0.47-4.39$ & $6.4-39.9$ \\
\hline
\end{tabular}

In European countries, the assessment of water quality for recreational water use, including bathing, is regulated by Bathing Water Directive 2006 (the first Directive was adopted in 1976). Implementation of the Bathing Water Directive is monitored by the European Environment Agency. According to the Seventh Environment Action Programme (7th EAP), bathing water quality must meet the "excellent" or "good" standard by 2020. Thanks to the reconstruction of the sewerage system, improved wastewater treatment, and reduce pollution of agricultural fields, the quality of bathing water in the EU countries is improving over time. In 2018, bathing water in EU countries met the standards of "excellent", "good" and "sufficient" by 95.4\% [17, 18]. Water quality studies must be conducted within 4 years. The main indicator of bathing water quality in EU countries is intestinal enterococci and Escherichia coli.

Detailed reports on bathing water quality are available to water users in Moscow and Moscow Region, Voronezh, Kursk, Orel, Tambov, Tula Regions on the Rospotrebnadzor website (www.rospotrebnadzor.ru). The ban on bathing is often linked to the nonconformity of a water body to sanitary regulations and conditions of safe use of the water body. Bathing in an untreated water body or a water body with a ban on bathing creates a threat of food poisoning, infection with acute intestinal infections, enterovirus, viral hepatitis "A", other infectious and parasitic, as well as fungal diseases.

In the CFD of Russia, recreation-accessible water bodies and watercourses can be found with restrictions (level 2 access), severe restrictions (level 3 access), but with high recreational potential, and recreation inaccessible (level 4 access).

Full access to information on water body access for recreational water use, including water quality, should be provided.

The recreational availability of large reservoirs and watercourses should be assessed in terms of sites suitable for recreation. They indicate the presence or absence of sources of pollution in the water body. The world experience of water quality control allows reducing the number of hydrochemical, microbiological and parasitological indicators if the 
indicators are stable and do not exceed MAC for a certain period and there are no new sources of pollution. Beach areas must be organized following GOSTs, bathing must have a sanitary and epidemiological certificate of Rospotrebnadzor. Artificial water bodies quarries and ponds, as well as outdoor and indoor pools near water bodies - are most suitable for recreational water use in the CFD of Russia. Water bodies or sites should have a status "for recreational water use" so that all measures are aimed at the protection of water bodies and their eco-rehabilitation.

The reported study was funded by RFBR, project number 18-35-00609.

\section{References}

1. Ministry economic development Russian Federation, Strategy for socio-economic development of the Russian Federation's constituent entities until 2030, [electronic resource], accessed at: https://old.economy.gov.ru/ (accessed on 15 January 2020).

2. A.P. Demi, Popular scientific encyclopedia «Water of Russia», Water use. [electronic resource], accessed at: http://www.water-rf.ru (accessed on 13 January 2020).

3. A.B. Avakyan, V.K. Bojchenko, V.P. Saltankin, Water Resources, Recreational use of water bodies of the Moscow region (state, problem and prospects), 4, 125-133 (1983)

4. M. Meybeck, Fresh surface water, Chemical characteristics of rivers, 1, 310-319 (2009).

5. Official statistics 2019 [electronic resource], accessed at: https://www.gks.ru (accessed on 15 January 2020)

6. Federal Service for Supervision of Consumer Rights Protection and Human Well-Being [electronic resource], accessed at: https://rospotrebnadzor.ru/ (accessed on 15 January 2020)

7. E.A. Chekmareva, Collection of conference materials Water resources of Russia: current state and management, Recreational accessibility of water bodies of the Central federal district (CFD), 1, 210-217 (2018)

8. GOST R 55698-2013 Tourist services. Beach services. General requirements, 16 (2013)

9. GOST 3161-2012 Water. General requirements for sampling, 32 (2013)

10. GOST 31942-2012 Water. Sampling for microbiological analysis, 24 (2011)

11. GN 2.1.5.1315-03. Maximum permissible concentrations (MPC) of chemical substances in the water of water objects of economic and drinking and cultural water use, 84 (2003)

12. Water code of the Russian Federation from 03.06.2006 N 74-FZ (ed. from 02.08.2019) (with ed. from 01.01.2020), 37 (2006)

13. O.A. Alekin, Basics of hydrochemistry, 446 (1970)

14. SanPiN 2.1.5.980-00 Hygienic requirements for surface water protection, 18 (2000)

15. E.A. Chekmareva, Water: chemistry and ecology, Water quality of recreationaccessible reservoirs and watercourses of the Central Federal district of Russia, 10-12, 68-73 (2019)

16. I.L. Grigoryeva, E.A. Chekmareva, Izvestiya RAN. Seriya Geograficheskaya, Influence of recreational water use on the water quality of the Ivankovsky reservoir, 3, 63-70 (2013)

17. European Environment Agency, European bathing water quality in 2018. Report 3 (2019)

18. European Environment Agency, Council Directive 2006/7/EC concerning the management of bathing water quality and repealing Directive 76/160/EEC // EU, OJ L $64,4.3,37-51,(2006)$ 